\title{
Recurrent seizures, progressive cognitive decline, Parkinsonism and a calcified brain: is it Fahr's disease?
}

\author{
Osama S M Amin
}

Department of Neurology, Sulaimaniya General Teaching Hospital, Sulaimaniya City, Iraq

\section{Correspondence to} Dr Osama S M Amin, dr.osama.amin@gmail.com
To cite: Amin OSM. BMJ Case Rep Published online: [please include Day Month Year] doi:10.1136/bcr-2013009853

\section{DESCRIPTION}

A 34-year-old man developed three generalised seizures over a period of 2 weeks. He had generalised rigidity and mild bilateral symmetrical resting tremor. His deep tendon reflexes were normal with downward planter reflexes. His elder brother noticed that the patient had a progressive cognitive decline over the past few years. He resides in a village and works in a grocery store. His blood tests, including serum calcium, phosphate, alkaline phosphatase and parathyroid hormone, were within their normal reference ranges. His non-contrast CT brain scan reveals widespread symmetrical intracerebral calcification (figures 1 and 2).

Most cases of Fahr's disease come into light during their third to fifth decades of life after demonstrating a variable combination of abnormal movements (dystonia, chorea), Parkinsonism, subcortical type of dementia, seizures (focal and/or generalised) and (uncommonly) pancerebellar dysfunction. The disease results from progressive and bilateral symmetrical calcification of the basal ganglia, thalami, subcortical white matter of the hemispheres and deep cerebellar nuclei; therefore, striatopallidodentate calcinosis is a more precise designation. ${ }^{1}$ The metabolisms of calcium kinetics and other minerals are normal.

Our patient was taking oral fluoxetine $(40 \mathrm{mg} /$ day) which was prescribed by his local general practitioner (GP); the progressive cognitive

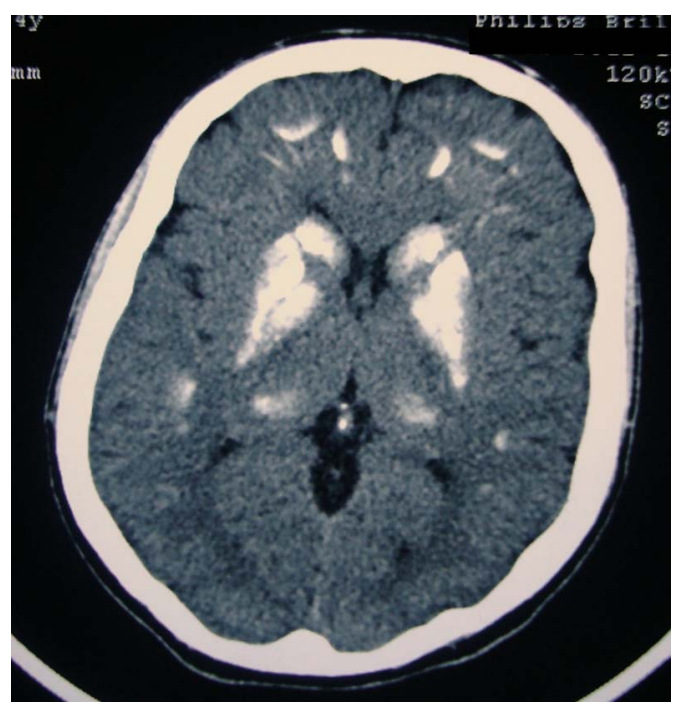

Figure 1 Non-contrast axial CT brain scan of the patient at the level of basal ganglia and thalami. Note the bilateral and symmetrical calcification of the putamen, caudate, thalami and subcortical white matter.

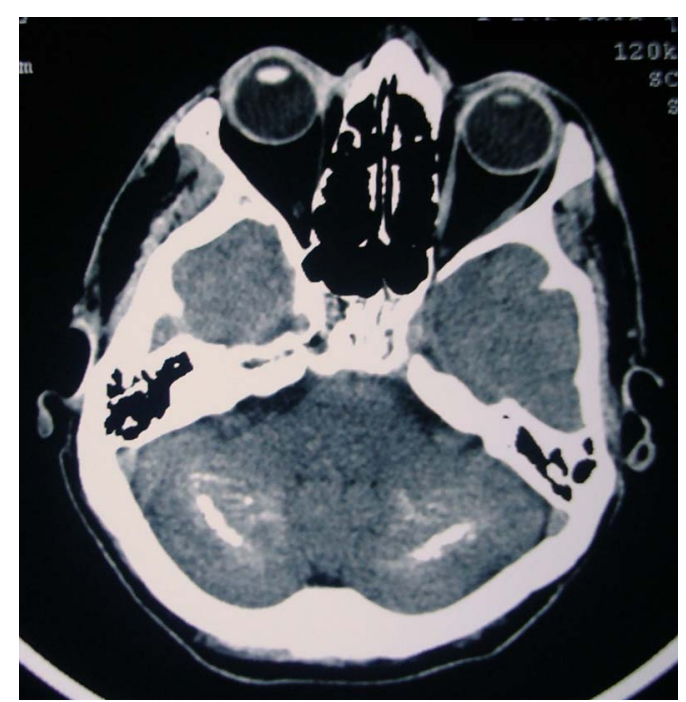

Figure 2 Non-contrast axial CT brain scan of the patient at the level of posterior fossa. Note the bilateral symmetrical calcification of the deep cerebellar nuclei.

impairment with generalised hypokinesia (and slow movements) might have prompted the GP to think of a depressive illness. The development of seizures (and subsequent CT brain findings) had uncovered the disease which the patient has.

In Fahr's disease, seizures are considered a rare manifestation, while involuntary hyperkinetic movements are the usual presenting features. ${ }^{2}$

\section{Learning points}

- Fahr's disease, or striatopallidodentate calcinosis, is a rare disease that has protean manifestations with a variable combination of abnormal movements, Parkinsonism, dementia, seizures and cerebellar dysfunction.

- Seizures, focal and/or generalised are rare presenting features.

- The development of progressive cognitive decline and Parkinsonism in young individuals should always prompt the physician to think of diseases other than depression.

Competing interests None.

Patient consent Obtained.

Provenance and peer review Not commissioned; externally peer reviewed. 


\section{REFERENCES}

1 Amin OSM. Fahr's disease and frontal lobe-like cognitive dysfunction. J Mood Disord 2012;2:119-22.
2 Hoque MA, Siddiqui MR, Arafat Y, et al. Fahr's disease: a very rare cause of epilepsy. Mymensingh Med J 2010;19:127-9.

3 Abubakar SA, Saidu S. Idiopathic bilateral strio-pallido-dentate calcinosis (Fahr's disease): a case report and review of the literature. Ann Afr Med 2012;11:234-7.

Copyright 2013 BMJ Publishing Group. All rights reserved. For permission to reuse any of this content visit http://group.bmj.com/group/rights-licensing/permissions.

BMJ Case Report Fellows may re-use this article for personal use and teaching without any further permission.

Become a Fellow of BMJ Case Reports today and you can:

- Submit as many cases as you like

- Enjoy fast sympathetic peer review and rapid publication of accepted articles

- Access all the published articles

- Re-use any of the published material for personal use and teaching without further permission

For information on Institutional Fellowships contact consortiasales@bmjgroup.com

Visit casereports.bmj.com for more articles like this and to become a Fellow 